\title{
Communications in Forestry 1
}

by

\section{Gilbert Paillé}

\section{Introduction}

I know nothing about communications, like most foresters. So, please don't give me bad marks if I don't deliver a good speech on the topic of communications. And like most foresters, I don't sing well, I don't dance, I don't play steel guitar and I don't speak in a perfect English. Therefore, you can rest assured that I know nothing about show business.

Like most foresters, I did my best before coming here this noon to dress up formally in order not to attract nasty comments or too much attention to my person. This way, I was sure to convince you that I know nothing either about public relations.

In my job, like most foresters, I avoid reporters like disease and I avoid spreading the bad news to be sure that I don't make the headlines of newspapers, or that I am not seen on "The National" at eleven.

Like most foresters, I don't address Lions' Clubs, Rotary Clubs, Richelieu Clubs or Chambers of Commerce. I don't write articles for wildlife, nature or outdoor mangazines. I don't belong to municipal, regional, provincial or national political parties. This way, I make sure that as few people as possible know me and what I am doing in life.

Like most foresters, I don't like to get myself too much involved into controversial topics of wide interest to the general public, such as the use of chemicals to reduce damages done by insects to the forest, the need to kill weeds in order to favor valuable species of trees, the use of heavy mechanical equipment to harvest wood, the replacement of hardwoods by conifers, or the need to set aside prime forest lands for posterity. Therefore, few people outside the forestry community are seeking my advice on such burning issues.

Finally, like most foresters, I am deeply involved in conducting massive forestry programs, deep in the woods, where most people don't go or are not attracted.

In preparing those programs, and in writing thousands of pages of reports to my boss on their evolution or completion, I avoid, like msot foresters, showing any material to noninterested parties in order to prevent them from complicating the problems, from cirticizing the methods, from anticipating the results, or from making pressure to stall the system. Therefore, nobody gives a damn about most forestry programs that I am conducting. This is probably why I still am not recognized in Canada as one of the then forestry leaders. But this gives me no pain because, as Joe O'Neill said, there are none yet.

Ladies and gentlemen, I told you right from the start that I knew nothing about communications. I hope that you are

\footnotetext{
1Presented to Canadian Institute of Forestry/Institut Forestier du Canada, August 1987
}

completely convinced by now. However, if I had all the decision tools in my hands, let me tell you what I would do to improve the situation.

In doing so, I realize that I would be going against one of the principles of communications as expressed by Jay Ingram which says that people are not interested in what you are going to do. However, since most of these ideas have already been tested or are currently in application, I hope that they will grab your attention.

\section{Communications With Awareness Programs}

First, I would stop doing most of what I just described in order to put myself in a better communicational attitude.

Second, I would, as suggested by Jacques Genest, "hit the brain" and apply the outside-in approach to myself by taking a course or two to acquire basic communication skills, develop some public relations abilities and improve my knowldge for marketing products and ideas.

Then, I would strongly advise school boards to include more notions about renewable natural resources in their educational programs for kids, because I am convinced that what you recognize early in life as being important grows on with you and strongly influences your future behaviour. Since it is no secret for anybody that Canadians badly need to develop an attitude of husbandry towards their forest resources and that whatever we do to the forest is left as a heritage to our children, it is most important that they understand better why we have done what we have done to our forest resources, and that they develop early a new and proper attitude towards them. This would constitute children awareness programs (CAP). They would of course supplement all existing educational programs for youngsters.

Claire Dalfen has already done that with a program called "People of the Forest"; it could also have been called "Hit the Children First" but such a title could have been misinterpreted .. This program does respect the purpose of communications which, as expressed by Alex Dickson, is to change attitudes. Since it takes 20 years to change people's attitude, we better begin soon and with the children.

As a second step, I would advocate the development of long-term municipal awareness programs (MAP). There are 900 communities in Canada where $15 \%$ or more of the labour force works in the forest sector. This is where the programs should be concentrated and this is supported by Max Keeping who suggested that we promote forestry in cities. One major purpose of these programs would be to factually inform these populations about the state of the forest and the forest industry on which their livelihood depends directly. They could be complemented by demonstration programs conducted along autoroutes, highways, regional and municipal roads linking these communities, to make the travelling population aware of the benefits which can be derived from good land-use and proper forest tending. 
In Quebec, for example, there are 60000 kilometers of such roads; if 500 metres of forest land were tended on each side, this would represent some 3 million ha of forests to be taken care of; if all present forest management activities were centred in these areas, this would create work for some 30 years at the present rate of forest tending. We can hypothesize that the cost/benefit ratio of such visible silviculture works would be improved substantially, and so would the public understanding.

John Spears has advocated that we should quantify the impact of inaction. You certainly don't need to be an economist to do that when travelling on most of our public roads in Canada. More often than not, you need only one hour in a pick-up truck through the backwoods to see improved forest stands. I have long wondered why foresters like to hide in order to do their good things!

A recommendation from the Canadian Forestry Forum just held in Saint John, New Brunswick, also indicates that the public should be better informed on forestry matters, and participate in forest management planning. Such activities could easily be included in the proposed municipal awareness programs.

As a third step, I would advocate the launching of interested public awareness programs (IPAP). This public is represented by members of some 150 non-governmental organizations related to the forest sector, by members of some 50 organizations of the so-called forest constituency, and by members of their families who are more informed and more receptive to natural resources information than the general public. This interested public would benefit from more information on the economic importance of the forest resources, and the importance of not only protecting them but also utilizing them for the public's well-being.

Here the concepts proposed by André Duchesne, Pat Duffy and Sandy Robertson could be put to use. In presenting a clear and simple message, an in developing a regional and national network of co-operating associations, teleconferencing and electronic information hot-lines would be useful tools to speed up the information flow and improve the exchange of information.

Finally, general public awareness programs (GPAP) aimed at the whole population should be maintained. Recent initiatives taken by the Canadian Council of Forest Ministers indicate that general public awareness can indeed be improved with well-planned and professionally oriented programs. The frequency and magnitude of such programs should however be substantially increased to make a significant and long-lasting impact on Canadians. Present forestry initiatives in that field are still very shy when compared, for example, with what breweries do to promote beer. They spend $\$ 10$ to $\$ 12$ million to launch a single new name, and each brewery is spending anywhere between $\$ 250$ and $\$ 400$ thousand in publicity and promotion to gain each market point.

In forestry, we have many points to earn and many names to launch. So, I think that we should spend much more on communications. Moreover, as suggested by Melissa Hadley, these expenses should be considered as a cost of growing the next crop of trees. Talking of names, it would not hurt to promote a modern forest hero; somebody like the Max Headroom of forestry; somebody who would take the dust off Jos Montferrand.

\section{Conclusion}

In summary, I am advocating a reversal of the funnel, and a stepping-up of the present approach to communications in forestry. Instead, of pouring publicity on the masses in order to reach every one, the suggestion consists of starting from the ground, and working upwards with a network of four interrelated, and well targeted programs (CAP - MAP - IPAP - GPAP). The suggestion also consists of linking information, promotion and publicity with education and demonstration. This would certainly have for a result a massive stepping-up of our efforts in communications.

Max Keeping went further in proposing that we should use all modern ways and means at our disposal to do the job. And Mrs. Harding said that if we want to be successful, we not only have to tell but we also have to listen since communication is a two-way exercise.

Earlier, I told you what I would do or what I would advise others to do if I had all the decision tools in my hands. But I don't. Therefore, and without being pessimistic, I suspect that what I will continue to do, like most foresters have done for at least the last 25 years, is work like a horse to make the system work. This means, make sure that the forest is protected against fires and insects; that it is accessed properly; that mature stands of trees are harvested with the best equipment possible and transported to hundreds of mills; that more and more emphasis is put on regenerating these stands of trees; that some research in done to improve our understanding and methods. Like most foresters, I will continue to worry about the little importance given by the general public to what we are doing. I will continue to belong to regional, provincial, national and international organizations of professional foresters. I will continue to write in forestry magazines, and to address foresters conventions and forums. I will continue to love the forest and the outdoors, and hate those people who criticize our work without knowing what we do while not understanding fully why we are doing it. And I will be prepared to speak to you again in 10 years deploring the lack of public awareness for forestry and stressing the urgent need for more communications. 